\title{
БИМ И ГЕОДЕЗИЈА
}

\author{
Игор Сабадош ${ }^{1}$ \\ Тоша Нинков ${ }^{2}$ \\ Маријана Петковић ${ }^{3}$ \\ Мехмед Батиловић ${ }^{4}$ \\ Ненад Антонић ${ }^{5}$
}

УДК: $004.4: 528$

DOI: 10.14415/zbornikGFS30.13

Резиме: Геодезија и грађевинарство су струке које тесно сарађују током реализаџије зграда, путева и разних инжењерских објеката. Предности БИМ технологије, која је пре свега алат намењен архитектама и грађевинским инжењерима увиђа и геодетска струка која жели да искористи њен потенцијал. У раду ће бити описана БИМ технологија и шта то имају заједничко БИМ и геодезија у савременом друштву.

Кључне речи: БИМ, БИМу геодезији,

\section{1. УВОД}

Комплексна архитектонска дела, савремене технике градње и управљање целокупним градилиштем не замисливо је радити без савремених технолошких и техничких решења. Једна од технологија која се истакла у руковођењу и управљању пројектом, градилиштем и управљањем у току експлоатације јесте БИМ (Building information modeling - информациони модел објекта) технологија.

БИМ је заправо сличан концепту PLM (Product Lifecycle Management - управљање животним веком производа) јер поред бављења физицким карактеристикама објекта дотиче и теме као што су: управљање трошковима, пројектни менаџмент, али и истовремени рад на већини различитих аспеката коришћења објекта. [1]

Иако БИМ није новина у свету, тек у последње време врши озбиљнији продор на тржиште. Па је тако у Северној Америци од 2007. године до 2012. године употреба БИМ, у разним сферама инжењерства, порасла је са $28 \%$ на $71 \%$. Свест о предностима БИМ пројектовања из године у годину расте и на нашим просторима и све више инжењера увиђа да је БИМ једно од најперспективнијих открића које своју примену налази у архитектури, инжењерству и грађевинкој индустрији. [2]

\footnotetext{
${ }^{1}$ Игор Сабадош, маст инж геод., Факултет техничких наука Нови Сад, e-mail: igorsabados@uns.ac.rs

${ }^{2}$ Проф. др Тоша Нинков, дипл инж геод., Факултет техничких наука Нови Сад, e- mail: ninkov.tosa@gmail.com

${ }^{3}$ Маријана Петковић, маст инж геод., Факултет техничких наука Нови Сад, e-mail: marijana.petkovic@uns.ac.rs

${ }^{4}$ Мехмед Батиловић, маст инж геод., Факултет техничких наука Нови Сад, e-mail: mehmed@uns.ac.rs

${ }^{5}$ Ненад Антонић, маст инж геод., Пољопривредни факултет Нови Сад, e-mail: nenadsbc@gmail.com
} 
У августу 2004. године Национални институт за стандарде и технологију САД (НИСТ) објавио је анализу трошкова услед лоше оперативности под именом Cost Analysis of Inadequate Interoperability in the U.S. Capital Facilities Industry. У закључку се наводи да лоша оперативност у индустрији кошта САД око 15,8 милијарди долара годишње. [3]

\section{2. ШТА JE ТО БИМ}

БИМ је свеобухватни процес пројектовања који почиње идејним пројектом објекта, а завршава се израдом пројектне документације за изградњу објекта, управљањем изградњом објекта и одржавањем објекта у фази експлоатације. Он може представити комплетан животни век објекта, од процеса градње до сценарија коришћења, тј. одржавања објекта.

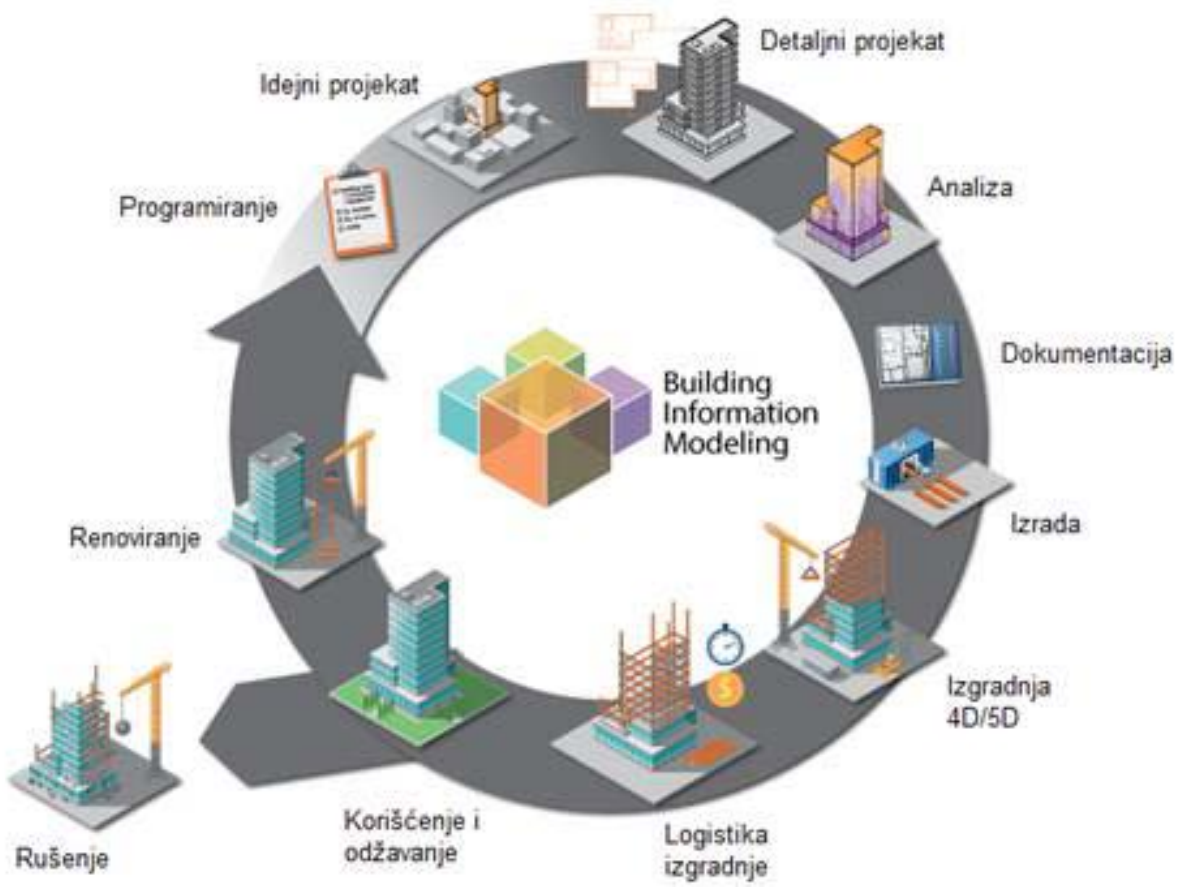

Слика 1. Илустрација шта је то БИМ

БИМ пружа једноставно добијање свих потребних информацијама о количинама (на пример, приликом израде спецификације и прорачуна трошкова). Инфорациони модел објекта обједињује геометрију, просторне односе, анализу осветљења, географске параметре, количине и технички опис елемената (на пример, детаље произвођача појединих елемената зграде). Обим и одређена поља рада могу бити издвојена из пројекта и посебно дефинисана. Системи, монтажа или делови објекта 
могу бити приказани у одговарајућој размери у односу на цео објекат или групу објеката. [1]

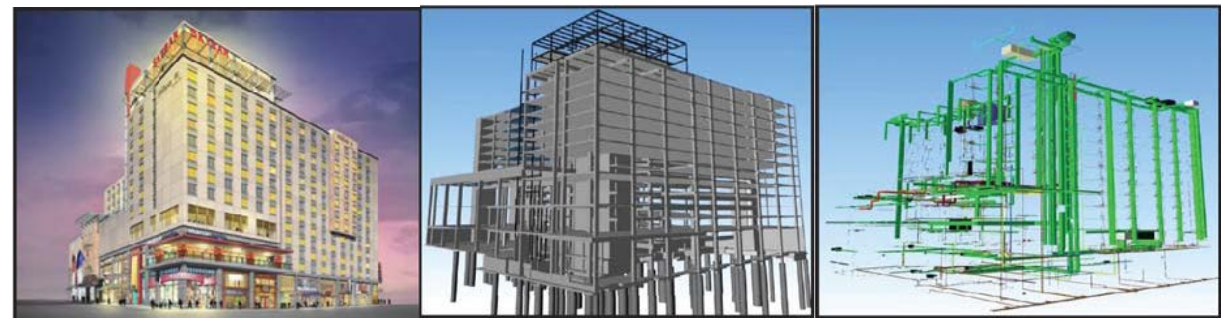

Слика 2. Издвојена поља рада из БИМ модела

БИМ представља генерисање и кориштење координисаног, јединственог и прецизног ЗД модела објекта који као подлогу има систем информација. Информације о пројекту које доносе поуздани дигитални прикази објекта могу се користити за: испитивање, анализу и симулацију различитих варијанти решења, израду прецизне и ажурне пројектне документације, предвиђање перформанси објекта у изграђеном окружењу, спецификацију материјала, процену трошкова изградње, и на крају, за управљање и одржавање објекта. [4]

\section{3. БИМ У АРХИТЕКТУРИ И ГРАЪЕВИНАРСТВУ}

БИМ је један од изума који много обећавају а своју примену налази у архитектури, грађевинарству и многим сферама инжењерства. У архитектури БИМ служи за потребе израде пројекта и детаљног ЗД модела у виртуелном окружењу. [5]

Након виртуелне изградње објекта омогућава брзу израду пројектне документације. Уколико се током изградње објекта указе потреба за изменом пројекта, све измене се врши на јединственом 3Д моделу.

Све мере потребне за изградњу се скидају директно са дигиталног модела, и тиме се спречавају грешке изградње услед двоструке документације. [6]

БИМ пружа једноставно добијање свих потребних информацијама о квантитету (на пример приликом израде спецификације потребних материјал, прорачуна трошкова итд.).

Он обједињује геометрију, просторне односе, анализу осветљења, географске параметре, количине и технички опис елемената (на пример, детаље произвођача појединих елемената објекта).

Одређена поља рада и обим радова могу бити издвојени из пројекта и посебно дефинисани. Системи, монтажа или делови објекта могу бити приказани у одговарајућој размери у односу на цео објекат или групу објеката што омогућава бољу прегледност и води ефикаснијем одлучивању. [1]

Израда информационог модела објекта омогућава детаљан преглед комплетног модела уз алгоритме за аутоматску детекцију лоших решења (укрштање више инсталација на не дозвољен начин) и тиме штеди време које би се утрошило на преправку пројекта када дође до проблема. 


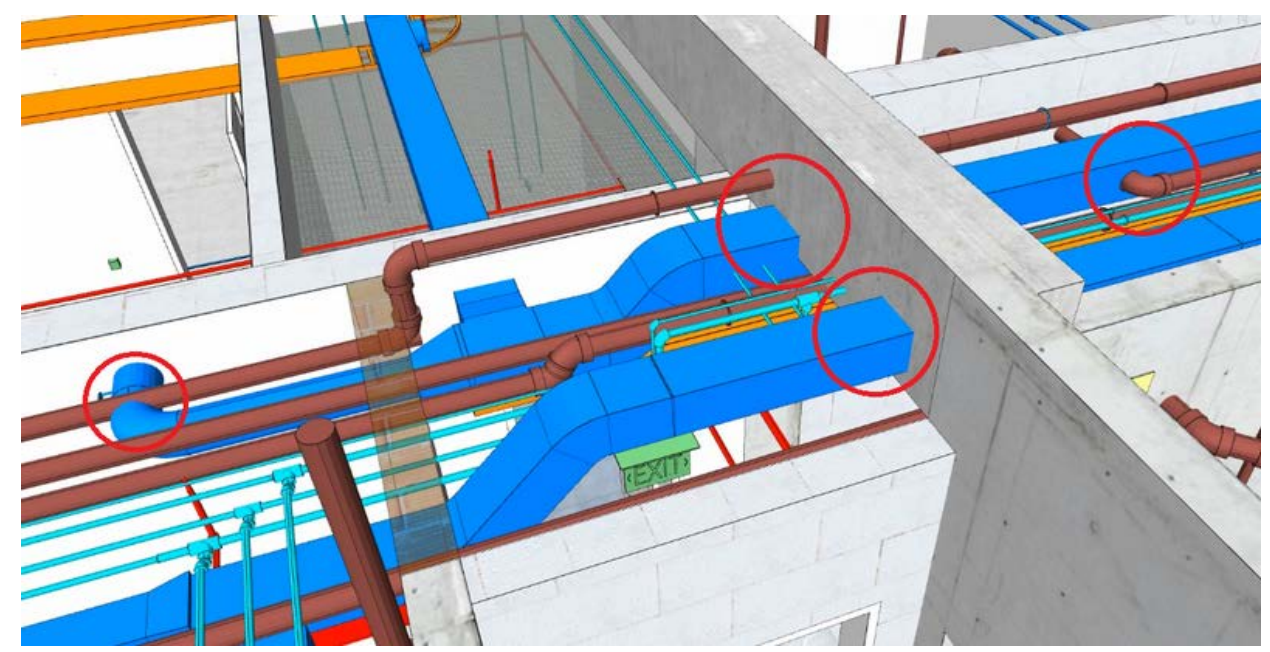

Слика 3. Аутоматска детекиија лоших пројектних решења

\section{1. БИМ у пројектовању и градњи путева}

Упркос томе што му стоји у имену, БИМ није ограничен само на примену у архитектури и зградараству. БИМ су врло брзо препознали и грађевински инжењери као алат који омогућава брзо и паметно пројектовање. [7]

Примена БИМ-а за пројектовање путева и аутоутева почиње израдом квалитетних ЗД подлога терена, као што су дигитални модел терена (ДТМ) и дигитални елевационог модела (ДЕМ).

Затим се наставља моделовањем на бази релевантних информација о дизајну и просторном положају пројекта. То доводи до израде интелигентног 3 Д модела пута (аутопута, тунела) чији елементи су повезани динамички, не само тачкама, површином, равнима, већ богатим скупом заједничких података. [8]
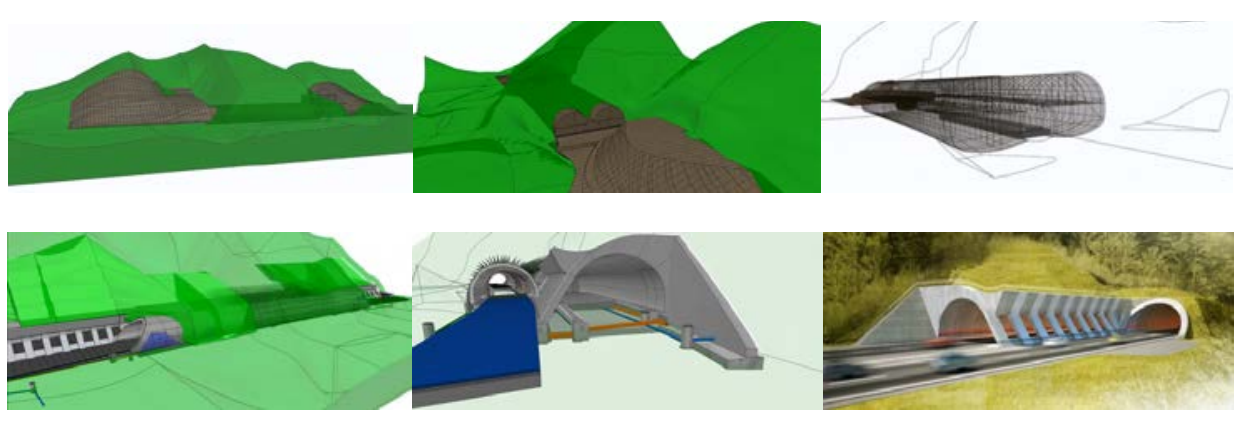

Слика 4. Композиција фотографија БИМ тунела у Словенији кроз фазе изградње (Bexel consulting) 


\section{2. Предности БИМ}

Бенефиције БИМ-а огледају се најпре у бољој визуализацији самог објекта клијенту у фази пројектовања, могућност да се објекат виртуелно изгради пре почетка радова. Тиме се пружа могућност клијенту да посматра процес изградње као и да учествује као део пројектног тима, чиме се смањује могућност сукоба интереса и тиме одређује јасан правац израде БИМ плана.

Такав омогућава изградњу без накнадних преправки објекта и као најважније оптимизује управљање животним циклусом објекта, што је од суштинске важности јер оперативни трошкови предтављају око 80\% укупних трошкова изградње. [9] Највеће предности БИМ-а јесте:

- боља визуелизација

- унапређена продуктивност због једноставне размене информација

- боља координација пројектних докумената

- додавање и повезивање кључних информација (спецификација материјала, положај детаља и параметри количина потребни за наруџбину и прорачун трошкова)

- брже пројектовање

- смањење трошкова.

Суштина је у томе да се БИМ не заснива на обичном дигиталном цртежу већ на комплетном детаљном моделирању објекта које чини да се свака измена аутоматски региструје у основама, пресецима, ЗД моделу.

Наравно, БИМ омогућава одличну комуникацију са ГИС алатима, као и програмима који врше прорачуне потрошње енергије и воде у зградама, анализу осветљености и проветрености просторија већ у пројектним фазама.

Овакве анализе омогућавају рано уочавање свих аспеката квалитета будућег објекта и брзу израду више варијантних решења што у значајној мери помаже у одлучивању.

Када се на поменуто дода да БИМ укључује и приказе који представљају процес градње или одржавање објекта током животног века, јасно је да класични $C A D$ програми, који су и даље апсолутни стандард у процесу пројектовања код нас, немају шансе у конкуренцији са БИМ-ом у времену које долази. [1]

\section{3. БИМ софтвери}

БИМ софтвере највише користе појединци, предузећа и владине агенције које се баве планирањем, дизајном, изградњом, управљањем и одржавањем различитих инфрастуктурних објеката као сто су: реке и канали, електро-енергетска и гасна постројења са пратећом мрежом, фабрике, путеви, мостови и многи други инфрастуктурни објекти. [5]

БИМ софтвери за пројектовање присутни су у грађевинарству већ преко две деценије.

Последњих година преузели су примат над класичним CAD концептом у свим водећим пројектним бироима света те је данас незамисливо радити велике пројекте без употребе БИМ технологије. 
Поред класичних геометријских информација, БИМ представља и просторне односе, анализу осветљења, географске параметре, количине и технички опис елемената нпр. детаље произвођача појединих елемената зграде. [1]

БИМ је интегрисан процес за истраживање кључних физичких и функционалних карактеристика пројекта у дигиталном облику пре почетка реализације пројекта.

Програм AutoCAD Civil 3D je Autodesk БИМ решење у нискоградњи. [11]

Софтвери засновани на БИМ концепту који се примејују у зградарству су бројни. Неки популарнији су: Revit, Tekla, AlarmCAD, ArchiCad, AutoCad AEC, Applications, AutoSPRINK, Bentley Building, CADPipe, Design Master Software, FireAcad, GenerativeComponents.

Revit софтвер је посебно направљен за БИМ , са циљем да оспособи архитектонске и грађевинске стручњаке да идеју доведу до изградње приступом заснованим на координираном и конзистентном моделирају.

То укључује функционалност свих Revit дисциплина (архитектура, машинство, енергетика, инсталације, грађевинарство) у један јединствени интерфејс.

Нека популарнија БИМ софтверска решења за моделовање цеви, инсталација и металних конструкија су: Revit, InfiPoints и EdgeWise.

\section{4. ГЕОДЕЗИЈА И БИМ}

Технолошки напредак остварен у последњим годинама може што се видети и у грађевинарству. Грађевине су све комплексније, градилишта већа а стилови градње комплекснији.

Управљање оваквим градилиштима представља својеврстан подухват а за квалитетно управљање неопходна је и квалитетна инвенторизација целокупног градилишта и кординирнање машина у процесу градње. Геодезија може понудити помоћ у овом процесу.

Улога геодезије у стварању БИМ-а јесте да на бази мерења обезбеди информације о физичким и функционалним карактеристикама места и презентује их у дигиталном формату.

Било да се ради о терену, пројекту праћења имплементације планске документације или о креирању БИМ-а постојећег објекта, савремене технологије прикупљања просторних података омогућују креирање детаљних и квалитетних дигиталних репрезента стварних објеката.

\section{1. Савремене технологије прикупљања просторних података}

Развој савремених геодетских технологија попут ласерског скенирања и UAV (Unnamed aerial vehicle - беспилотна летелица) омогућио је прикупљање велике количине просторних података у кратком временском интервалу.

Ласерско скенирање представља прикупљање просторних података помоћу ласерског зрака при чему се региструје рефлексија од препреке у правцу емитовања 
зрака, и на основу мереног угла и растојања одређују X, Y, Z координате тачке, док се скуп тачака назива облаком тачака.

Поред података о апсолутним или релативним координатама може садржати и податак о интензитету одбијеног ласерског зрака. [8]

Како је принцип рада веома сличан разликујемо статичко и мобилно ласерско скенирање. Статичко или терестричко ласерско скенирање је погодније за скенирање објеката попут зграда, мостова, индустријских постројења.

Разлог томе је већа релативна тачност која је резултат близине инструмента објекту снимња, што води лакшем и прецизније уклапању више скенова.

Динамичко скенирање је погодније за прикупљање информација о већим поршинама као што су коридори, веће земљане површине за потребе изградње индустријских постројења и томе слично без прекидања рада.

Иако употреба беспилотних летелица (UAV) није нова појава, доскоро је примену налазила само у осматарчким мисиијама за војне потребе. Тек у последњих неколико година нашла је своју примену у геодезији у оквиру аерофотограметрије и направило праву револуцију. Мале димензије и велика мобилност система чине га веома погодним за потребе снимања земљишта средње величине, снимања у урбаним и тешко приступачним срединама, мапирању унутрашњости објеката и сл. Такође у последње време развијене су и летелице које имају могућност ношења ласерских скенера. [13]

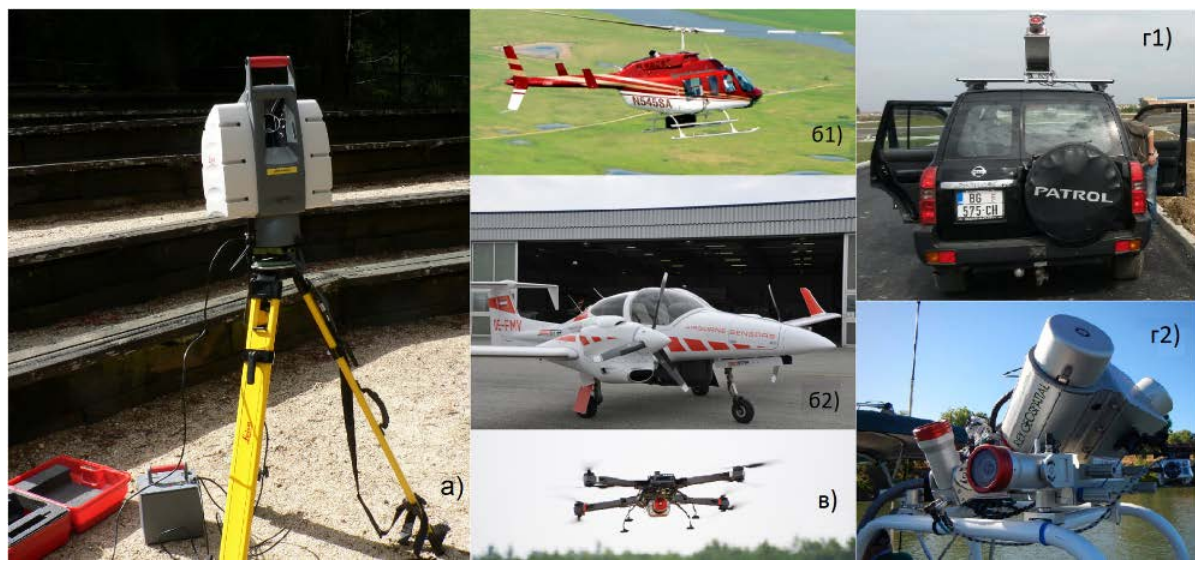

Слика 5. а) Статички ласерски скенер б1) и б2) Авионско ласерско скенирање в) Динамички ласерски скенер монтиран на UAV 21) и г2) Мобилно ласерско скенирање

Док ласерско скенирање и беспилотне летелице омогућавају прикупљанје информација о површини, георадари пружају могућност регистрације карактеристика објекта испод површине. Технологија се заснива на емитовају и простирању електормагнетног таласа, одређене фреквенције, кроз медијум и његове рефлексије и регистровања. Као продукт снимања добија се радарграм на ком се могу уочити прелази из оптички ређе у оптички гушћу средину и обрнуто, што омогућава регистровање дебљине словева земљишта, цеви, кабловаи осталих објеката подземне инфраструктуре, као и дебљине слојева на путевима. [2] 


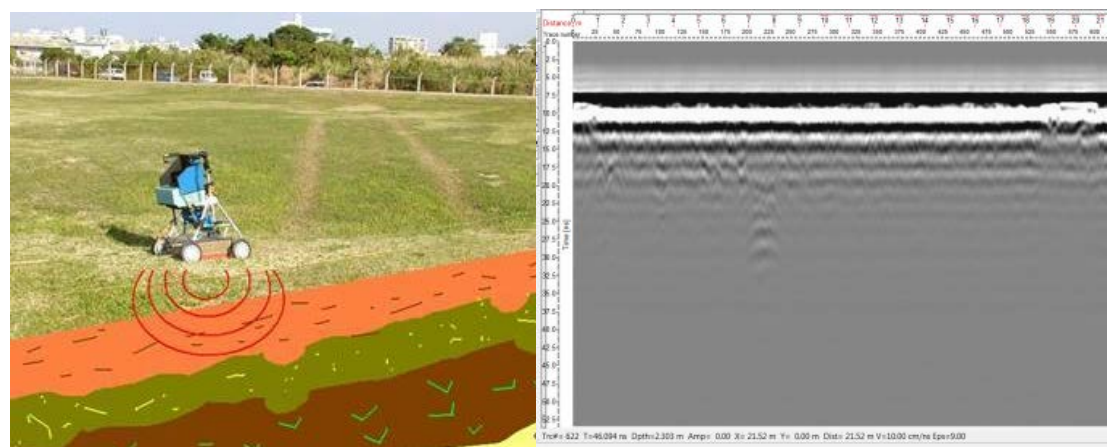

Слика 6. Георадара (лево), радарграм (деесно)

\subsection{1. Продукти снимања}

Продукт ласерскогскенирања представља дигитални геореференцирани облак тачака првог и последњег еха, као и РГБ и НИР снимак рефлектујуће површине. Ласерски скенери новије производње могу мерити и до 1000000 тачака по секунди. Овакве перформансе уређаја пружају могућност регистрације облака тачака са веома великом густином тачака, која пружа веома добар увид у сваки детаљ објекта од интереса и омогућава веома прецизно моделирање. [12] Продукт снимања беспилотним летелицама јесте велики број фотографија високе резолуције, које се Postflight режиму аутоматски или полуаутоматски обједињују у специјализованим софтверима. Као продукт оваквог поступка креира се дигитални орто-фото план уз могућност креирања облака тачака снимљеног окружења. [14] Комбиновањем података прикупљених поменутим технологијама могуће је креирати дигитални модел терена (ДМТ) и дигитални елевациони модел (ДЕМ) као и дигиталне моделе објеката. БИМ сачињавају фајлови, који поред информација о површини и просторном положају могу носити и информацију о власништву, саставу тла и многим другим специфичностима, и на тај начин помоћи у доношењу одлука о карактеристикама одређеног места.

\section{2. БИМ У УПРАВЉАЬУ ЗЕМЉИШТЕМ И КАТАСТРУ}

Управљање земљиштем и катастром јесте још једна од сфера где БИМ тражи своје место. БИМ потенцијално може понудити неке погодности у управљању слојевитим катастарским простором у урбаним срединама. Као прво, нестручна лица би имала боље визуелно испреплитаних, комплексних катастарских података. Широк спектар просторних и семантичких информација о физичким структурама унутар модела омогућио би разумевање катастарских граница, пружајући недвосмислену поделу власништва, права, обавеза и ограничења. Осим тога, коришћењем БИМ за управљање катастарским подацима могло би унапредити постојећи аналогни 2 Д система управљања земљиштем у ЗД дигитални, интелигентни, интерактивни и динамички. [15] Такође БИМ би омогћио и интерактивно управљање животним циклусом објекта и тиме омогућио информисање о вредности објекта. [16] 
Тренутни тренд и технологије које се користе за управљање земљиштем у развијеним земљама базиран је на CityGML структури и VRML визуализацији.

\section{3. БИМ у контроли изградње}

Код традиционалног приступа контрола изградње се може вршити у грубим оквирима и то пре свега у габаритима објекта док контрола унутрашњости се готово не практикује и прецизна реализација се своди на умеће мајсотра. Развој савремених геодетских технологија попут ласерског скенирања па чак и беспилотних летелица омогућио је прикупљање велике количине просторних података у кратком временском интервалу. Као продукт продукт примене поменутих технологија могуће је креирати ЗД модел изведеног стања објекта који се може се користити за разне анализе и компарацију пројекта и изведеног стања, контроли пођтовања урбанистичких услова, што представља значајан корак у контроли изградње и омогућује брз увид у евентуално неслагање. Прикупљени подаци се такође могу користити за моделовањеунутрашњих и спољашњих површина објекта у поступку стварања БИМ постојећег објекта. Ово је од посебног значаја приликом управљања већим и комплекснијим градилиштем. [6]

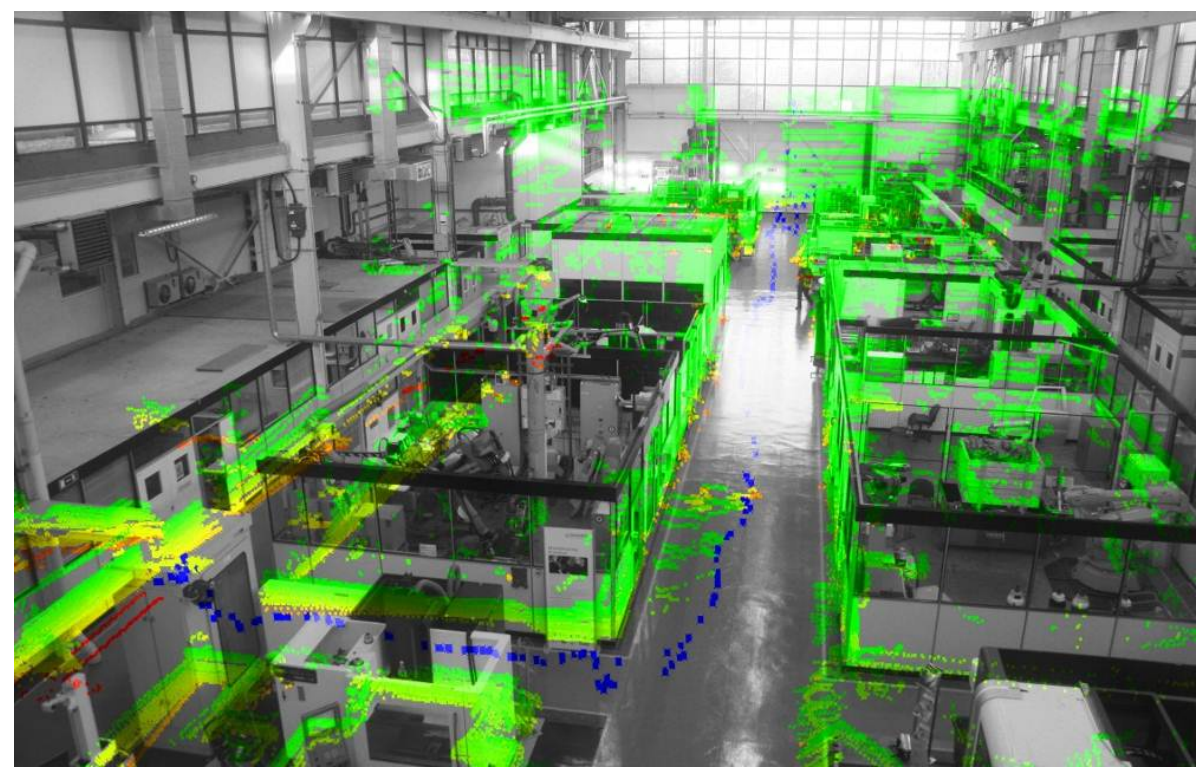

Slika 7. Primena UAV u kotroli implementiranja unutrašnje infrastrukture objekta

\section{4. Креирање БИМ постојећих објеката [семинарски]}

Увиђањем значаја и предности ове технологије у новије време у развијемни земљама јавља се потреба за креирањем БИМ постојећих објеката а геодезија представља кључ у том процесу.

У развијеним земљама већ неко време тежи се ка томе да се направе и БИМ-ови за старе објекте, али то наравно носи многе проблеме са собом јер БИМ, да би имао 
пуног смисла, мора садржати све информације а уношење само оних познатих представља потенцијалну опасност, јер, једном навикнути на БИМ, они који у њега буду гледали подразумеваће да се у њему налази апсолутно све са чим могу да се сретну у једном објекту. [1]

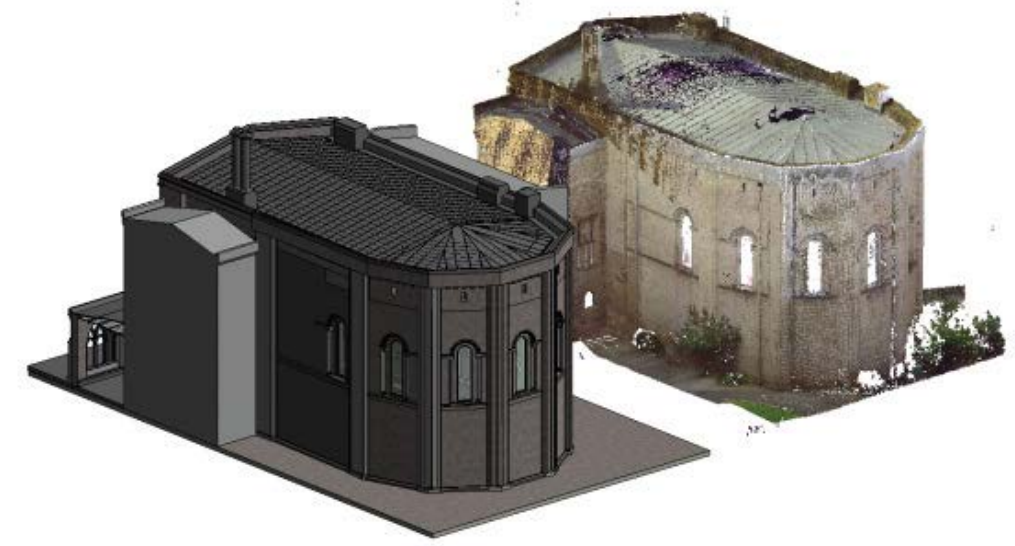

Слика 8. Главна зграда Дурхам катедрале у Лондону, модел и облак тачака

Примена LiDAR и $U A V$ технологије омогућује креирање детаљног геореференцираног површинског модела објекта, било да се ради о објекту, унутрашњости објекта или о путу, аутопуту или сличном. Док нам ласерско скенирање и $U A V$ омогућава креирање површинског модела, георадар нам омогућава да завиримо испод површине и прикупимо значајне информације.[2]

Примена георадара, $L i D A R$ и $U A V$ технологија омогућује прецизних информација који представљају основу за креирање детаљног ЗД модела. У наредној фази стварања БИМ постојећег објекта потребно базу података допунити значајним информацијама о деловима објекта. У случају путева то би могло бити уједно и контрола изградње јер пружа увид у дебљину слојева пута као и регистрацију пратецих водова и инсталација. Информације од значаја за базу података могле би се тицати ко је извођач радова и коштање радова, година изградње, произвођачи појединих делова објекта и рок трајања истих, димензије појединих делова, информације о одржавању и потрошњи и многе друге. Информације од значаја за цеви могле би се тицати профила, материјала, обима, притиска у цеви, материјал, шта кроз њу протиче и томе слично. Тиме би се заокружио процес креирања и остварила даља могућност премене ове технологије у даљој експлоатацији објекта.

\subsubsection{Indoor ласерско скенирање}

Један од последњих трендова јесте ласерско скенирање унутрањих површина илити “indoor ласерско скенирање“" и креирање 3Д модела. Досадашњи принцип се базирао на моделовању на основу 2Д планова и слика или уклапањем више скенова добијених терестричким ласерским скенирањем. Код комплексинијих унутрашњих простора, пре свега индустријиских постројења, јавља се потреба за флексибилнијим системом мапирања. [17] 


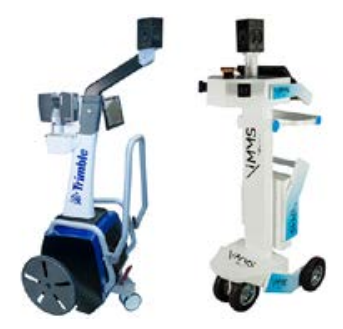

Slika 8. Новија решења "indoor" мобилних ласерских скенера

Технологијом мобилног скенирања донекле је решен проблем уклапања различитих скенова и углова видљивости и омогућено прецизније одређивање међусобних растојања између објеката. Међутим један од главних недостака ове технологије и њене примене у затвореном јесте одређивање позиције уређаја на основу података са ГНСС пријемника и угловних отклона забележених инерцијалном јединицом. Ове компоненте у једном интегрисаном систему дају одличне резултате на отвореном простору али губитак сигнала са сателитима и грешка инерцијалне јединице која са временом експоненцијално расте до поновног успостављања сигнала чине главни недостатак технологије и њене примене у затвореном. Оно што омогућава превазилажење ових недостатака јесте калманово филтрирање које комбинује податке прикупљене са различитих сензора и врши корекције и даје статистички оптималну процену прошле, тренутне и будуће позиције. [17]

Посебан значај ове технологије огледа се на примеру мапирања унутрашњости и спољашњости индустријских постројења скоја се састоје из мноштва цеви, затварача и резервоара.

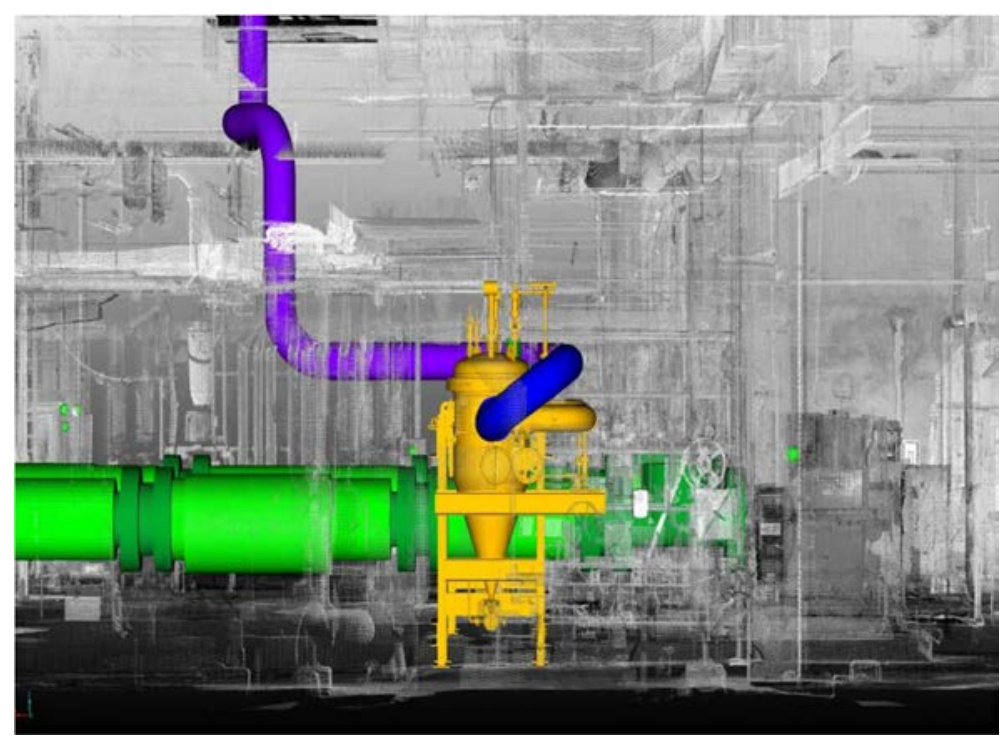

Slika 9. Преклопљени облак тачака и ЗД модел 


\section{5. ЗАКЉУЧАК}

БИМ је богат подацима, објектно орјентисан, интелигентан и параметарски дигитални репрезент стварног објекта који омогућава различитим корисницима различите погледе. Издвајање податке од интереса омогућује вршење анализа и симулација из којих могу проистећи значајне инфорамције, које могу бити употребљене у процесу одлучивања и доношењу одлука и на основу којих се може унапрадити процес изградње објекта. [18]

Информациони модел објекта постао је иновативан начин управљања пројектима. Многи истраживачи и практичари су показала да је БИМ технологија неопходна за пројектовање и изградњу објеката исто као чекић и ексер. Како се употреба БИМ-а повећава, сарадња пројектних тимова расте, што ће довести до побољшања профитабилности, смањења трошкова, боље управљање временом и побољшане односе са клијентима.

Поред бројних предности које ова технологија доноси у грађевинској индустрији остале струке не би смеле занемарити њене могућности и требале би искористити њен потенција. Савремено управљање простором и свиме ониме што га чини и испуњава захтева употребу савремених технологија и алата што БИМ свакако јесте а пун потенцијал ове технологије и све њене могућности остаје да истражимо у периоду који је пред нама. До тада једно је сигурно, БИМ јесте неопходанк корак напред за развој пре свега грађевинске индрустије и урбанистићко управљање простором, а своју шансу не би смело да пропусти ни мноштво других струка.

\section{ЛИТЕРАТУРА}

[1] „Build“ magazin br 15, Septembar 2010

[2] Ninkov T., Sabadoš I., Sušić Z., Batilović M., Bulatović V., BIM tehnologija i njena primena kod projektrovanja i gradnje puteva, Drugi srpski kongres o putevima, Jun 9-10., 2016., Beograd,

[3] http://www.gradjevinarstvo.rs/tekstovi/2099/820/perspektive-razvoja-gradjevinskeindustrije-u-2012-godini

[4] http://autodesk.osa.rs/proizvodi/arhitektura-i-gradjevinarstvo

[5] Salman Azhar, Abid Nadeem, Johnny Y. N. Mok, Brian H. Y. Leung, 2008. Avgust 4-5, „Building Information Modeling (BIM): A New Paradigm for Visual Interactive Modeling and Simulation for Construction Projects“, Proceedings of First International Conference on Construction in Developing Countries, "Advancing and Integrating Construction Education, Research \& Practice”, Pakistan, Karachi, str 435-446

[6] Ninkov T.,Sabadoš I., Ninkov J., BIM tehnologija i njena primena u postupku praćenja implementacije planske dokumentacije u urbanim sredinama, 12. Naučno stručni skup „Letnja škola urbanizma“, Maj 17-19., 2016., Jagodina

[7] http://acronymonline.org/bim-isnt-buildings-means-public-sector-highway-design/

[8] http://cenews.com/article/6098/what_does_bim_mean_for_civil_engineers

[9] https://surveyorsblog.wordpress.com/2013/02/19/building-information-modelling/

[10] http://en.wikipedia.org/wiki/Building_information_modeling

[11] http://www.teamcad.rs/ 
[12] Ninkov T., Sušić Z., Bulatović V., Sabadoš I., Batilović M., 22. April 2016., „Oblak tačaka i 3D model izvedenog stanja kao osnova održavanja i sanacije objekata“: Zbornik radova 4. Međunarodne konferencije „Savremena dostignuća u građevinarstvu“, Građevinski fakultet Subotica, str 971-977

[13] Sušić Z., Ninkov T., Bulatović V., Vasić D., (2014): Primena bespilotnih letelica u postupk u izradi geoprostornih podloga za projektovanje. 5. Internacionalni naučnotehnološkiskup „Građevinarstvo - nauka i praksa“, Žabljak, Crna Gora, ISBN 97886-82707-23-3.

[14] http://spatialtechnologies.ca/wp-content/uploads/2014/03/eBee-brochure.pdf

[15] Atazadeh Behnam, Kalantari Mohsen, Rajabifard Abbas, Ho Serene, Ngo Tuan. "Building Information Modelling for High-rise Land Administration". Transactions in GIS, 14.03.2016.doi:10.1111/tgis.12199. ISSN 1467-9671

[16] Behnam Atazadeh, Mohsen Kalantari, Abbas Rajabifard, Tom Champion. "Filling the space". RICS Land Journal. Royal Institution of Chartered Surveyors. 23.02.2016.

[17] http://www.ifp.uni-stuttgart.de/publications/phowo11/210hyyppa.pdf, Preuzeto: 11.09.2016.

[18] CityGML - 3D Geospatial and Semantic Modelling of Urban Structures, T. H. Kolbe, 21.03.2007., Institute for Geodesy and Geoinformation Science, Berlin University of Technology

\section{BIM AND GEODESY}

Summary: Surveying and Construction are the professions that work closely during the implementation of buildings, roads and various engineering structures. Benefits of BIM technology, which is a tool primarily intended for architects and building engineers, realizes and geodetic profession that seeks to exploit its potential. The paper will be described BIM technology and what it has in common with geodesy in modern society.

Keywords: BIM, BIM in geodesy 